Rahmawati, S.Gz, M.Si.

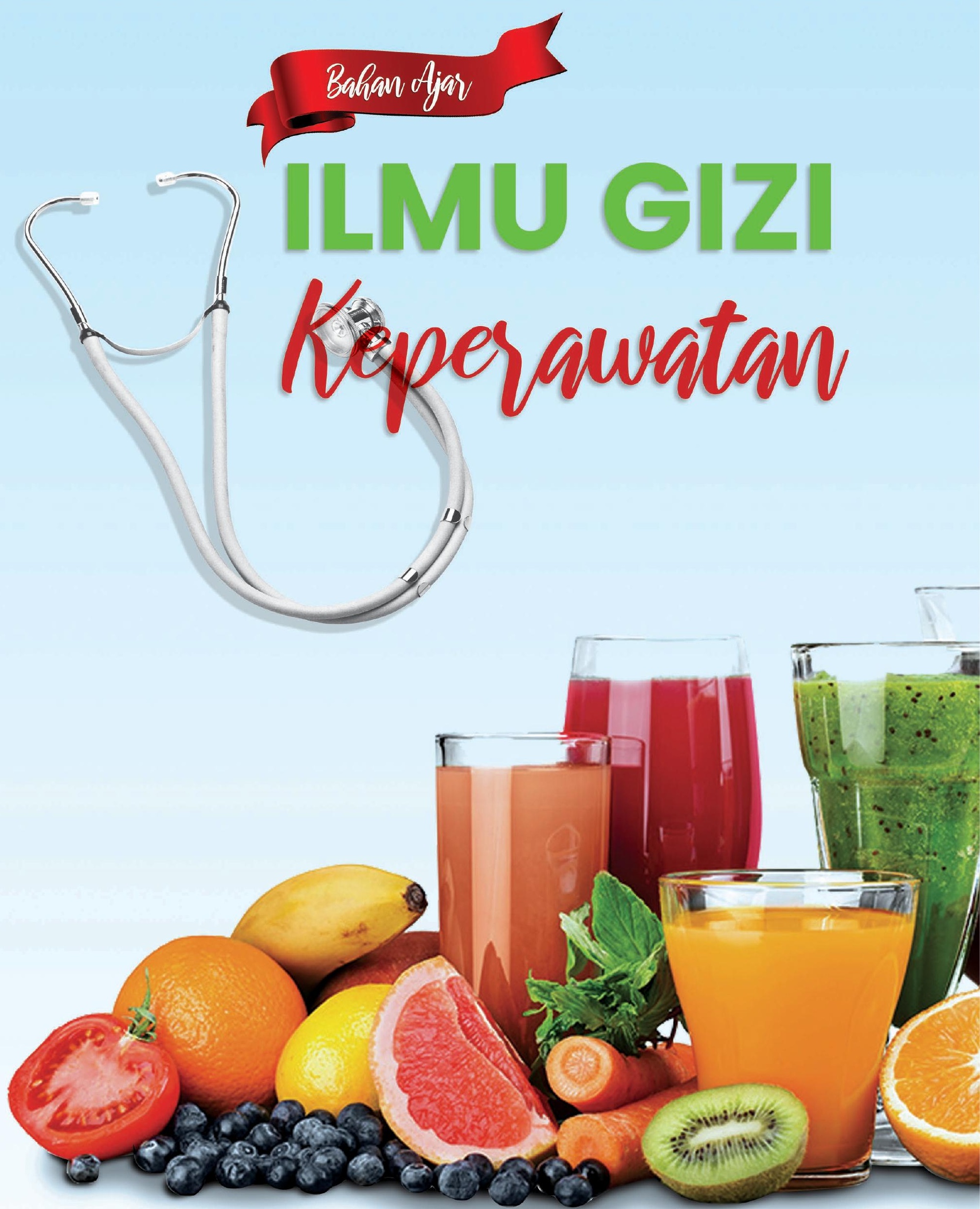


ILMU GIZI KEPERAWATAN 
KUTIPAN PASAL 72:

Ketentuan Pidana Undang-Undang Republik

Indonesia

Nomor 19 Tahun 2002 tentang HAK CIPTA

1. Barang siapa dengan sengaja dan tanpa hak melakukan perbuatan sebagaimana dimaksud dalam Pasal 2 ayat (1) atau Pasal 49 ayat (1) dan ayat (2) dipidana dengan pidana penjara masing-masing paling singkat 1 (satu) bulan dan/atau denda paling sedikit $\mathrm{Rp} 1000000,00$ (satu juta rupiah), atau pidana penjara paling lama 7 (tujuh) tahun dan/atau denda paling banyak Rp 5000000000,00 (lima milyar rupiah)

2. Barang siapa dengan sengaja menyiarkan, memamerkan, mengedarkan, atau menjual kepada umum suatu ciptaan atau barang hasil pelanggaran Hak Cipta atau Hak Terkait sebagaimana dimaksud dalam ayat 1 , dipidana dengan pidana penjara paling lama 5 (lima) tahun dan/atau denda paling banyak Rp 500000000,00 (lima ratus juta rupiah) 
Rahmawati, S.Gz, M.Si

\section{ILMU GIZI KEPERAWATAN}




\section{ILMU GIZI KEPERAWATAN}

Copyright (C) 2020

Penulis:

Rahmawati, S.Gz, M.Si

Editor:

Moh Nasrudin

(SK BNSP: No. Reg. KOM.1446.01749 2019)

Setting Lay-out \& Cover:

Tim Redaksi

Diterbitkan oleh:

\section{Pustaka Indonesia}

Jl. Raya Wangandowo, Bojong

Pekalongan, Jawa Tengah 51156

Telp. (0285) 435833, Mobile: 0853-2521-7257

pustakaindonesia90@gmail.com

Hak Cipta dilindungi oleh Undang-Undang

Dilarang memperbanyak sebagian

atau seluruh isi buku ini tanpa izin tertulis dari Penerbit

Cetakan ke-1, November 2020

\section{ISBN: 978-623-94433-3-7 (PDF)}




\section{Kata Pengantar}

Alhamdulillah, segala puji dan syukur penulis panjatkan kehadirat Allah SWT karena buku ini telah selesai disusun. Buku ini disusun agar dapat membantu para mahasiswa dalam mempelajari seluk beluk tentang ilmu gizi khususnya mahasiswa keperawatan beserta mempermudah mempelajari materi ilmu gizi terutama bagi kaum awam yang belum mengenal ilmu gizi itu sendiri.

Penulis pun menyadari jika didalam penyusunan buku ini mempunyai kekurangan, namun penulis meyakini sepenuhnya bahwa sekecil apapun buku ini tetap akan memberikan sebuah manfaat bagi pembaca. Akhir kata untuk penyempurnaan buku ini, maka kritik dan saran dari pembaca sangatlah berguna untuk penulis kedepannya.

Penulis,

Rahmawati, S.Gz, M.Si 


\section{Daftar Isi}

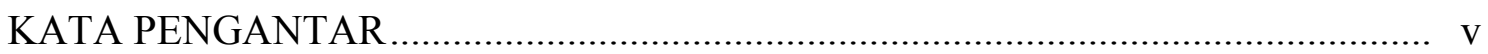

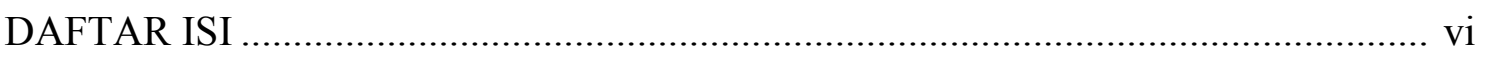

BAB I. KONSEP DASAR ILMU GIZI ....................................................... 1

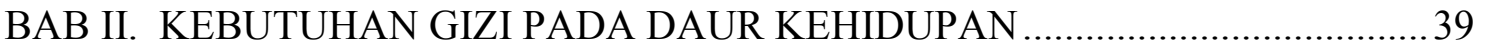

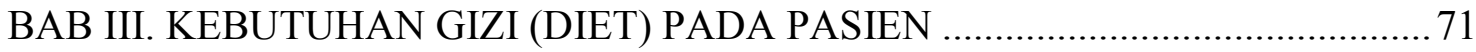

BAB IV. APLIKASI ILMU GIZI DALAM KEPERAWATAN .................................. 91

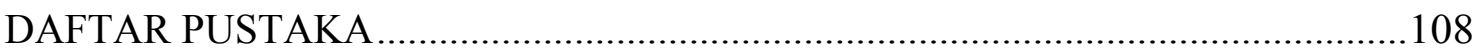




\section{BAB I}

\section{KONSEP DASAR ILMU GIZI}

\section{Pengenalan Ilmu Gizi}

Ilmu gizi adalah ilmu yang mempelajari segala sesuatu tentang makanan dalam hubungannya dengan kesehatan optimal. Kata gizi berasal dari bahasa Arab "ghizda" yang berarti makanan. Ilmu gizi juga berkaitan dengan tubuh manusia.

Dalam mempelajari ilmu gizi tak lepas dari beberapa istilah yang harus diketahui sebagai dasar untuk petugas kesehatan. Adapun istilah dalam ilmu gizi antara lain:

a. Zat gizi (nutrients) adalah ikatan kimia yang diperlukan tubuh untuk melakukan fungsinya, yaitu menghasilkan energi, membangun dan memelihara jaringan serta mengatur proses-proses kehidupan.

b. Gizi (nutrition) adalah suatu proses organisme menggunakan makanan yang dikonsumsi secara normal melalui proses digesti, absorpsi, transportasi, penyimpanan, metabolisme, dan pengeluaran zat-zat yang tidak digunakan, untuk mempertahankan kehidupan, pertumbuhan dan fungsi normal dari organ-organ, serta menghasilkan energi.

c. Pangan adalah istilah umum untuk semua bahan yang dapat dijadikan makanan.

d. Makanan adalah bahan selain obat yang mengandung zat-zat gizi dan atau unsurunsur atau ikatan kimia yang dapat diubah menjadi zat gizi oleh tubuh, yang berguna bila dimasukkan ke dalam tubuh.

e. Bahan makanan adalah makanan dalam keadaan mentah.

f. Status gizi adalah keadaan tubuh sebagai akibat konsumsi makanan dan penggunaan zat-zat gizi.

\section{Sejarah Perkembangan Gizi}

Sejak jaman purba ilmu gizi sebenarnya sudah dikenal memiliki fungsi sebagai makanan untuk mempertahankan hidup. Kemudian Hippocrates (460-377 SM) sebagai bapak ilmu kedokteran mendefinisikan ilmu gizi sebagai pemeliharaan kesehatan dan penyembuhan penyakit dasar terapi diet. Cornaro (1366-1464) dan Francis Bacon (1561-1626) juga mendifinisikan ilmu gizi sebagai kegiatan makan yang diatur dengan baik sehingga dapat memperpanjang umur. Antoine Laurent Lavoisier (1743-1794) juga mendifinisikan ilmu gizi sebagai hubungan proses pernapasan dengan proses pengolahan makanan. Magendie (awal abad-19) telah membedakan berbagai macam zat 


\section{BAB II}

\section{KEBUTUHAN GIZI PADA DAUR KEHIDUPAN}

\section{Kebutuhan Gizi Bayi}

Makanan terbaik bagi bayi adalah air susu ibu (ASI) sampai berumur 2 tahun, dimana sampai 6 bulan pertama hanya ASI tanpa disertai makanan atau minuman lain (ASI ekslusif). Mulai umur 6 sampai 24 bulan pemberian ASI harus disertai makanan lain (MPASI) karena kualitas dan kuantitas ASI tidak mampu lagi memenuhi kebutuhan bayi yang terus tumbuh. Jumlah kebutuhan ASI bagi bayi tidak dibatasi, kapan bayi mau menyusu harus diberikan.

\section{- ASI dan kebutuhan gizi bayi}

Air susu ibu merupakan makanan ideal untuk bayi terutama pada 6 bulan pertama. ASI mengandung semua zat gizi yang diperlukan untuk pertumbuhan yang optimum dan penyediaan energi yang cukup. ASI tidak memberatkan fungsi alat pencernaan dan ginjal yang belum berfungsi baik pada bayi baru lahir. Lagi pula ASI memiliki berbagai zat anti infeksi, mengurangi kejadian ekstrim dan proses menyusui menguntungkan ibunya dengan terdapatnya lactational infertility hingga memperpanjang paritas.

Komposisi ASI berbeda dengan susu sapi. Perbedaan yang penting terdapat pada konsentrasi protein dan mineral yang lebih rendah dan laktosa yang lebih tinggi. Lagi pula rasio antara protein whey dan kasein pada ASI (60/40) jauh lebih tinggi dibandingkan dengan rasio tersebut pada susu sapi (20/80). Kasein di bawah pengaruh asam lambung menggumpal hingga lebih sukar dicerna oleh enzim-enzim. Protein pada ASI juga mempunyai nilai biologi tinggi sehingga hamper semuanya digunakan tubuh.

Dalam komposisi lemak, ASI mengandung lebih banyak asam lemak tidak jenuh yang esensial dan mudah dicerna, dengan daya serap lemak ASI mencapai 85-90\%. Asam lemak susu sapi yang tidak diserap mengikat kalsium dan trace elemen lain hingga dapat menghalangi masuknya zat-zat tadi.

Keuntungan lain ASI ialah murah, tersedia pada suhu yang ideal, selalu segar dan bebas pencemaran kuman, menjalin kasih saying antar ibu dan bayinya serta mempercepat pengembalian besarnya rahim ke bentuk sebelum hamil. Zat anti infeksi dalam ASI antara lain: 


\section{BAB III}

\section{KEBUTUHAN GIZI (DIET) PADA PASIEN}

\section{Jenia Diet}

Pasien yang sedang dirawat di rumah sakit menderita berbagai macam penyakit dengan klasifikasi penyakit yang begitu banyak, jadi untuk setiap pasien makanan yang dimakan disesuaikan dengan kondisi penyakitnya. Sebelum melangkah ke pembahasan mengenai diet. Untuk standar makanan umum artinya tidak memerlukan diet khusus dikenal ada beberapa jenis makanan yaitu makanan biasa, makanan lunak, makanan saring, dan makanan cair.

\section{- Makanan Biasa (MB)}

Makanan ini sama dengan makanan sehari-hari yang beraneka ragam, bervariasi dengan bentuk, tekstur, dan aroma yang normal. Susunan makanan mengacu pada Pola Menu Seimbang dan Angka Kecukupan Gizi (AKG) yang dianjurkan bagi orang sehat. Makanan biasa diberikan kepada pasien yang berdasarkan penyakitnya tidak memerlukan makanan khusus (diet). Walaupun tidak ada pantangan secara khusus, makanan sebaiknya diberikan dalam bentuk yang mudah dicerna dan tidak merangsang saluran cerna misalnya bumbu tidak terlalu banyak, tidak terlalu pedas atau asin. Contoh pasien yang mendapatkan jenis makanan biasa misalnya conjungtivitis tanpa demam, penyakit kulit yang bukan alergi, low back pain, penyakit pada hidung telinga dan tenggorokan (THT) yang tidak memerlukan operasi.

Tujuan diet adalah memberikan makanan sesuai kebutuhan gizi untuk mencegah dan mengurangi kerusakan jaringan tubuh.

Syarat diet pada makanan biasa adalah

a. Energi sesuai kebutuhan normal orang dewasa sehat dalam keadaan istirahat

b. Erotein $10-15 \%$ dari kebutuhan energi total

c. Lemak $10-25 \%$ dari kebutuhan energi total, 4) karbohidrat $60-75 \%$ dari kebutuhan energi total, 5) cukup mineral, vitamin, dan kaya serat, 6) makanan tidak merangsang saluran cerna, dan 7) makanan sehari-hari yang beraneka ragam dan bervariasi. 


\section{BAB IV}

\section{APLIKASI ILMU GIZI DALAM KEPERAWATAN}

\section{Masalah Gizi}

Pada saat ini, Indonesia menghadapi masalah gizi anda, yaitu masalah gizi kurang sekaligus masalah gizi lebih. Masalah gizi kurang pada umumnya disebabkan oleh kemiskinan; kurangnya persediaan pangan; kurang baiknya kualitas lingkungan (sanitasi); kurangnya pengetahuan masyarakat tentang gizi, menu seimbang dan kesehatan; dan adanya daerah miskin gizi.

Masalah gizi kurang di Indonesia saat ini meliputi : 1) Kurang Energi Protein (KEP), 2) Anemia Defisiensi Besi , 3) Gangguan Akibat Kekurangan Yodium (GAKY), 4). Kurang Vitamin A (KVA). Sebaliknya masalah gizi lebih disebabkan oleh kemajuan ekonomi pada lapisan masyarakat tertentu disertai dengan kurangnya pengetahuan tentang gizi, menu seimbang, dan kesehatan. Masalah gizi lebih ini adalah obesitas.

Masalah gizi akan mempengaruhi kecerdasan dan produktivitas seperti tergambar pada Tabel 18 berikut ini :

Tabel 18. Masalah Gizi dan Pengaruhnya IQ

\begin{tabular}{|l|l|l|l|}
\hline Masalah gizi & $\begin{array}{l}\text { Jumlah } \\
\text { penderita }\end{array}$ & IQ lost & Total IQ lost \\
\hline $\begin{array}{l}\text { GAKY } \\
\text { CEBOL } \\
\text { - GONDOK } \\
- \text { Risiko Daerah Endemik }\end{array}$ & $\begin{array}{l}900.000 \\
10 \text { juta } \\
42 \text { juta }\end{array}$ & $10-50$ & 140 juta \\
\hline Anemi gizi besi pada Balita & 8.1 juta & $5-10$ & $40-85$ juta \\
\hline Gizi buruk & 1.5 juta/th & $10-13$ & 19.5 juta \\
\hline Masalah gizi & Jumlah & Dampak \\
\hline Anemia gizi besi pada Usia produktif & 51.8 juta & $\begin{array}{l}\text { MENURUNKAN } \\
\text { PRODUKTIVITAS 20 - 30\% }\end{array}$ \\
\hline Kurang Vitamin A sub linis & 10 juta anak & $\begin{array}{l}\text { - Merusak sistem kekebalan } \\
\text { - Meningkatkan resiko kematian }\end{array}$ \\
\hline Masalah gizi usia dewasa : Gizi lebih & $>10$ juta orang & $\begin{array}{l}\text { Penyakit tidak menular/ } \\
\text { degeneratif }\end{array}$ \\
\hline
\end{tabular}




\section{DAFTAR PUSTAKA}

Almatsier. S. 2003. Prinsip Dasar Ilmu Gizi. Cet. 3. Gramedia, Jakarta.

Almatsier. S. 2004. Penuntun Diet. Edisi Baru. Gramedia, Jakarta.

Arisman. 2004. Gizi dalam Daur Kehidupan, Cet. I. EGC, Jakarta.

Beck, Mery. E. 2011. Ilmu Gizi dan Diet. Yogyakarta: Yayasan Essentia Medica.

Budiyanto, Agus Krisno. 2001.Dasar-Dasar Ilmu Gizi.Malang: UMM Pres.

Depkes RI. 2000. Gizi Seimbang Menuju Hidup Sehat bagi Balita. Jakarta: Dit. Bina Gizi

Depkes RI. 2000. Gizi Seimbang Menuju Hidup Sehat bagi Usia Lanjut. Jakarta: Dit. Bina Gizi.

Dwijayanthi, Linda. 2011. Edisi 2 Ilmu Gizi Menjadi Sangat Mudah. Jakarta: EGC

Fajar SA 2018. Buku Saku Gizi. Catatan Ahli Gizi. (e-book)

Gibson RS. 2005. Principles of Nutitional Assessment. New York : Oxford University. (e-book)

Guyton, Hall. 1997, Buku Ajar Fisiologi Kedokteran, Edisi 9. Jakarta : EGC.

Hartono A. 2006. Terapi Gizi dan Diet Rumah Sakit. Jakarta: EGC.

Kemenkes RI. 2019. Peraturan Menkes RI. No. 28 Tahun 2019: Angka Kecukupan Gizi yang Dianjurkan untuk Masyarakat Indonesia.

Lutz Carrol, Mazur E, Litch N. 2015. Nutrition and Diet Terapy (Six Edition). (e-book) Mahan KL, S. Escott-Stump. 2000. Krause's Food, Nutrition and Diet Therapy. Philadhelphia: WB Saunders Co, Ed 10.

Mardalena I, Suryani E. 2016. Ilmu Gizi. Modul Bahan Ajar Cetak Keperawatan. Kemenkes RI. (e-book)

Parth, Erna Francin. 2004. Gizi dalam Kesehatan Reproduksi. Jakarta : EGC

PERSAGI. 2010. Penuntun Konseling Gizi. Jakarta: PT. Abadi.

Poedyasmoro. 2005. Buku Praktis Ahli Gizi. Jurusan Gizi Poltekkes Malang.

Pudjiadi. 2003. Ilmu Gizi Klinis pada Anak. Edisi 4. Jakarta: FK UI.

Sediaoetama, Ahmad Djaelani. 2004. Ilmu Gizi I. Jakarta : Dian Rakyat.

Sediaoetama, Ahmad Djaelani. 2006. Ilmu Gizi II. Jakarta : Dian Rakyat. 
Soekirman. 2006. Hidup Sehat Gizi Seimbang dalam Siklus Kehidupan Manusia. PT Primamedia.

Soetjiningsih. 1997. ASI Petunjuk untuk Tenaga Kesehatan. Cet. I. Jakarta: ECG.

Sugiyono. 2010. Metode Penelitian Kuantitatif, Kualitatif dan R \& D. Bandung : Alfabeta.

Supariasa IDN, Bakri B, Fajar I. 2001. Penilaian Status Gizi. Jakarta: EGC. 


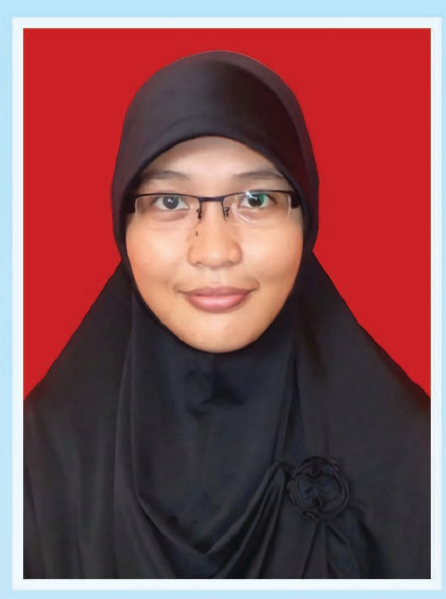

Rahmawati lahir di Maros 12 Agustus 1988. la lulusan S1 Ilmu Gizi Fakultas Kesehatan Masyarakat Universitas Hasanuddin tamat 2011. Setelah selesai pendidikan, ia bekerja sebagai Koodinator Tenaga Gizi di Puskesmas Weriagar Dinas Kesehatan Bintuni Papua Barat selama kurun waktu 2011-2013, kemudian melanjutkan pendidikan S2 di Ilmu Gizi Masyarakat Fakultas Ekologi Manusia tamat 2015 dengan bantuan beasiswa BPPDN calon dosen Tahun 2013.

Setelah menempuh pendidikan S2, ia kemudian mengabdikan diri menjadi dosen di STIKes Salewangang Maros pada periode 2015-2018 dan memiliki jabatan sturktural sebagai Ketua Prodi di S1 Ilmu Gizi, kemudian pada Tahun 2019, ia menjabat sebagai ketua LPPM dan UPM di Akademi Keperawatan Yapenas 21 Maros pada periode 2019-2023. Beberapa hibah penelitian ia telah raih selama menjadi dosen, diantaranya pada Tahun 2018 lolos hibah PDP, pada Tahun 2019 lolos hibah PKPT dan PKMS. Publikasi jurnal ilmiah juga telah diraih mulai dari jurnal nasional sampai jurnal internaisonal. Selain menyibukkan diri dalam penelitian dan pengabdian, ia juga aktif dalam pengelolaan jurnal di bawah naungan LPPM Akper Yapenas 21 Maros, ia juga aktif sebagai reviewer jurnal di institusi lainnya. Adapun buku yang sudah diterbitkan yaitu Buku Ajar IImu Gizi Keperawatan pada Tahun 2020.
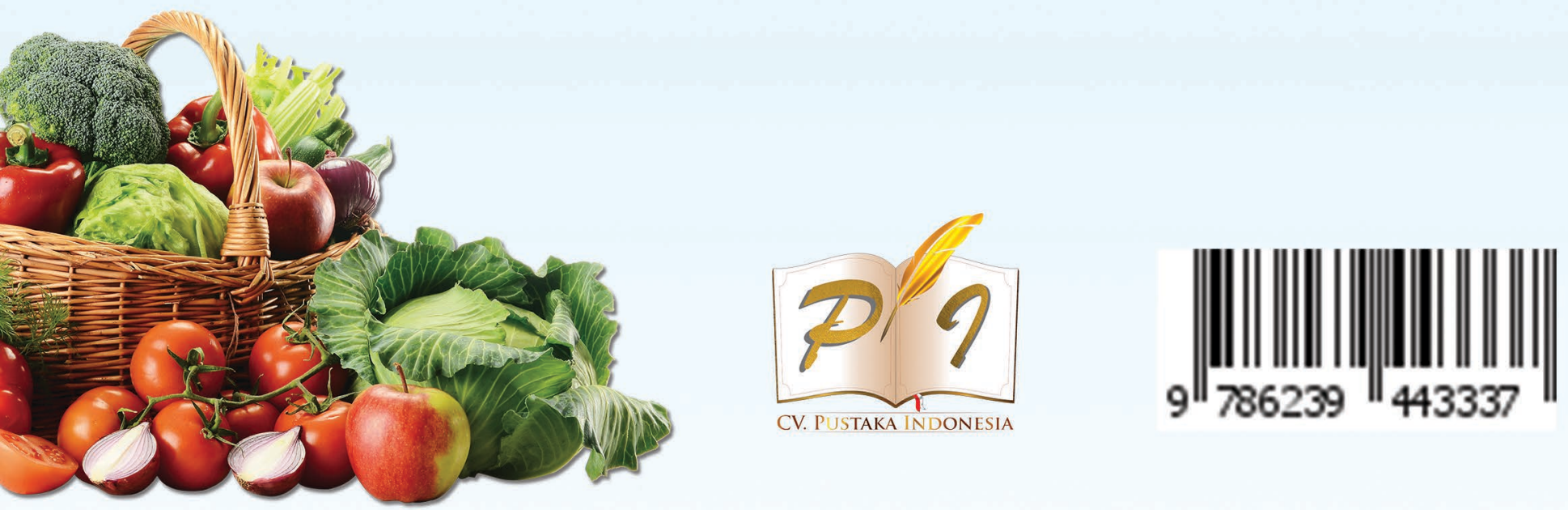